\title{
Politics and Public Service Human Resource Management Systems in Malawi
}

\author{
Lewis B Dzimbiri ${ }^{1, *}$ \\ ${ }^{1}$ Department of Political and Administrative Studies, University of Malawi, Chancellor College, Box 280 Zomba, \\ Malawi \\ *Correspondence: Department of Political and Administrative Studies, University of Malawi, Chancellor College, \\ Box 280 Zomba, Malawi. E-mail: proflewisdzimbiri@gmail.com/ldzimbiri@cc.ac.mw
}

Received: January 4, 2016 Accepted: February 11, $2016 \quad$ Online Published: March 17, 2016

doi:10.5430/wjss.v3n2p9 URL: http://dx.doi.org/10.5430/wjss.v3n2p9

\begin{abstract}
The public service is the main tool governments use to implement various national development policies and deliver services. An efficient public service requires a good interface between the political and administrative leadership to ensure that polices are formulated and implemented properly. The relationship between politics and administration has been a controversial subject in public administration. This paper examines the role and impact of politics on public service human resource management systems in Malawi. How people are recruited, selected, appointed, oriented, trained, promoted rewarded or disciplined affect their commitment, motivation and productivity. While at the formal level, ministers do not have prominent role in recruitment, promotion, demotion or transfer of public servants, in practice, political interference in appointments, promotion, transfer and demotion of public servants is widely perceived in the Malawi public service. The paper concludes with optimism that if the Vice President-led system-wide public sector reform recommendations are implemented properly, some of the challenges regarding political interference in public sector human resource management will be reduced.
\end{abstract}

Keywords: politicians, public service, principal secretaries, government, interface, policy making, policy implementation, policy evaluation, public sector reforms

\section{Introduction}

The public service is the main tool governments use to implement various national development policies and deliver services in education, health, community development, transport, maintenance of law and order among others (Dzimbiri, 2008). It is seen as pivotal for the growth of African economies and the creation of an appropriate and conducive environment in which all sectors of the economy can perform optimally. Governments rely on this machinery to design, formulate and implement its policies, strategies and programmes, and to discharge all routine government functions.

The overall objective of the paper is to analyse the role and impact of politics on public service human resource management systems and service delivery in Malawi. Using a purposive sampling technique in a cross-sectional study design employing in-depth interviews and questionnaires, the study focused on ministers and principal secretaries and human resource management directors in key ministries like Agriculture, Office of the President and Cabinet, Education, Health and the Department of Human Resource Management and Development. The questionnaires solicited responses regarding broad roles of ministers and PSs in relation to policy formulation, implementation, monitoring and evaluation. Specific questions concentrated on the role of ministers and principal secretaries in public service human resource management especially recruitment, promotion, demotion, discipline and transfers.

Data collected was analyzed through content analysis to derive themes and subthemes based on the responses to questionnaires and in-depth interviews guided by the study objectives. This also applied to secondary data from documents and reports. Central issues examined include the role of top public servants and politicians in the public 
administration system in Malawi and determine the nature and impact of the relationship between top public servants and cabinet ministers on the recruitment, promotion, transfer and discipline of senior public servants and determine the impact of that role on human resource management and service delivery in government departments.

The human resource is the most important and strategic resource for the implementation of national development policies. The manner in which they are recruited, selected, appointed, oriented, trained, rewarded or disciplined affect their commitment, motivation and productivity.

After this introduction, the paper provides the context of the Malawi public service followed by an analysis of politics-administration dichotomy framework. The role of ministers and principal secretaries in public policy processes and human resource management in the public service in Malawi is examined. The last part concludes the discussion.

\section{Malawi: Public Service Context}

Malawi became independent from Britain in 1964. Since then, she moved from a multiparty to one party dictatorship and then back to multiparty democracy in the 1990s. In the 1960s through the 1970s and 80s, Malawi developed Statement of Development policies as development roadmaps. However, the 1990s saw the development of Malawi Poverty Reduction strategy, then Vision 2020 and the Malawi Growth and Development Strategy (MGDS) 1 and 11 as a medium term development policy to ensure that Malawi realizes her national long term development direction embodied in the Vision 2020.

These national documents provide areas and directions for the investment of national efforts. These include sustainable economic growth, social development; social support and disaster risk management; infrastructure development; governance and gender and capacity development. They also include agriculture and food security; energy, industrial development, mining and tourism; transport infrastructure and Nsanje World Inland Port. Key priority areas for these national documents are: education science and technology; public health, sanitation, malaria and HIV and AIDS management; integrated rural development; green belt irrigation and water development; child development, youth development and empowerment; climate change, natural resources and environmental management are its key priority areas (DHRMD, 2013).

In order to accomplish the foregoing national aspirations, a properly engaged, motivated, trained, disciplined and professional public service is a must. However, to realise such calibre of the public service, a good political-administrative interface within the public service cannot be over-emphasised since the roles and responsibilities of ministers and principal secretaries are intrinsically linked although they have their own respective duties to perform.

However, the relations between them may be complicated and fraught with tensions. Politicians may complain that the administrators deliberately delay projects or that they are not loyal. On the other hand, PSs may cite inappropriate interference or micro-management in matters of human resources or finance. The Commonwealth Association of Public Administration and Management (CAPAM, 2007) regional seminar noted several challenges that PSs face in leading their ministries under the political leadership of ministers. These include the challenge of delivering results through others, clarity of purpose between PS and minister; managing complexity, speaking truth to power; building trust; and leading change. According Walters (2007), ministers and principal secretaries have distinct roles, responsibilities and accountabilities which have the potential to create friction. He argues that the fact that politicians are often rushing to get things done in order to deliver results for their constituency while the principal secretary can afford to take a long term view is a recipe for tensions.

While the public service should operate independent of the political executive, in many if not most governmental contexts in the Commonwealth, government could not function on such a basis. Public servants are deeply enmeshed in supporting the political executive as it forms and finalizes policy preferences. Public servants help in shaping legislation and have a leading role in the drafting of regulatory and policy instruments to further legislative aims. Public servants give life to government programs through the exercise of discretion and control over implementation. Public servants are responsible for oversight through internal audits and accountability measures. In many of these settings, senior public servants work hand in glove with political staff in the employ of ministers (Walters, 2007).

In the the 1960s and 70s, ministers in Commonwealth Africa were more dependent on the advice of principal secretaries but from the 1980s, however, the role of ministers had changed to the extent that most ministers are not only involved in policy-making, but are also interested in ensuring that those policies and relevant programmes and projects are effectively implemented (Kathyola, 2010). As more educated ministers with public sector experience 
were coming on the scene, the tendency for ministers to do much more than their predecessors increased, with some of them performing roles that traditionally belong to the principal secretary. Most ministers sometimes usurp the roles of a principal secretary (Kathyola, 2010).

Ordinarily, as head of the professional public service, principal secretaries would be heads of their ministries in the professional and administrative areas. They should therefore be responsible for bringing the necessary human resources to perform various activities in the ministries. They ought to be responsible for formulating, implementing and evaluating human resource management policies. Experiences of most Commonwealth countries in Africa indicate that a negative and/or non-productive relationship between a minister and a principal secretary, for example, can divide a ministry, turn it into a micro-political battlefield and undermine its overall effectiveness (CAPAM, 2007). A positive relationship between these two on the other hand can motivate the whole organisation to deliver, regardless of the level of technical, managerial and leadership competencies of the minister.

In Malawi, the Department of Human Resource Management and Development (DHRMD) under the Office of the President and Cabinet (OPC) is responsible for public service administration and management on behalf of the Chief Secretary to the Government. Its vision is "a high quality and result-oriented public service" and its mission is "to foster and sustain a high quality and result-oriented, accountable and transparent public service through the development and implementation of equitable, sound human and institutional resource management policies, strategies, practices and systems in order to ensure efficiency and effectiveness" in the public service. DHRMD is responsible for the administration and management of the public service in all the line ministries and departments through its human resource representatives.

The public service consists of mostly educated, well trained career-oriented personnel. These include primary and secondary school teachers, field assistants, community development staff, agricultural officers, executive officers, clerical and accounting staff, secretarial staff, human resource officers, administrators, and various professional and technical staff like engineers, scientists, doctors, health professionals, directors, undersecretaries, lawyers, judges and magistrates, among others.

These work in ministries of agriculture, health, education, office of the president and cabinet, department of human resource management and development, foreign affairs and international cooperation, local government, defence, labour, youth and manpower development, finance, economic planning and development, lands and housing, natural resources and climate change, transport and public works, Industry and trade (Dzimbiri, 2014). They also work in the police, prisons, local government as well as in the other branches of government, like courts and parliament as well as other public institutions city, municipal, town and district councils, parastatal bodies and commissions (ibid).

As a former British colony (1891-1964) Malawi's public service was shaped by the British public service in terms of rules and regulations and governing principles which embraced the principles recommended in the Northcoate-Trevelyan Report (1853): political impartiality; objectivity; integrity; accountability; confidentiality, open recruitment, promotion on merit basis. A series of public service reforms were implemented as outocmes of studies starting with the Skinner commission and later the Herbercq commission all of which called for the re-organization of the public service in terms of structures, governing principles and condition of service. The guiding principles of 1961 Public Service Commission on recruitment, promotion and discipline was promoting efficiency and effectiveness in the delivery of public services. Although political will and seriousness of the executive leadership led to measurable success in the delivery of public services, the administrative structures remained highly centralized and and expatriate-influncd in management style (Kachimera, 2014)

The transition to the multiparty era in 1994 led to a transformation of the public service which led to the birth of trade unions in the public service to engage government in negotiations for better conditions of services. The public service commission continued to observe and adhere to its fundamental principles of fairness, openness and appointment on merit. A Public Service Act, 1994 was enacted to compliment the Constitution of the Republic of Malawi, 1994 which was framed with a view to address the ills of human rights violations during the one party system of government. The immediate challenge was to see how best to balance the need for continuity of any best public service systems and practices and resolutely leaving out the negative aspects of the previous government. However, the new found freedom led to lawlessness in the name of claims of basic human rights. The public service once renowned for discipline during the one-party politial system became a laughing stock as public servants resorted to doing what pleased them( Kachimera, 2014) 


\section{Politics and Administration Dychotomy: A Theoretical Framework}

The relationship between ministers and principal secretaries in policy processes need to be understood in the context of the various arguments for or against the separation of politics from administration. The politics-administration dichotomy is the underpinning feature of Max Weber's (1980) ideal bureaucracy where the main role of politicians is policy making while administrators tackle the task of policy implementation (Rosenbloom 2008). Weber saw administrators as instrumental and subordinate to politicians and that they should function as technical experts who should advise and efficiently execute the decisions of politicians as the sovereign representative. However while politicians are in charge of defining the policies to be implemented by bureaucrats, Weber feared that career civil servants might dominate politicians through their superior knowledge, technical expertise and longer experience, in contrast to the ministers who change frequently. The question of the dichotomy between public administration and politics has remained an important question since the emergence of public administration as a field of study in the late 1880 s.

Wilson (1887) argued for the separation of politics from public administration when he pointed that public administration "lies outside the proper sphere of politics." (p. 210). The politics-administration dichotomy is based on the notion of dividing governmental authority between elected and administrative officials along functional lines. Public administration scholars proposed numerous explanations and theoretical models in their attempts to understand the role of public administration in the political process. Three schools- separation, political, and interaction have emerged to explain politics-administration dichotomy.

The separation school analyzes the relationship between politics and administration. It argues that the function of politics is to provide guidance, or what Wilson (1887) said, "setting the task for administration" and public administration functions to provide neutral competence to the policy process. Elected officials provide political guidance through policy leadership and legislative oversight. Policy leadership links elected officials to citizens, while legislative oversight links them to public administrators. On the other side of the policy process stands public administration whose primary responsibility is to enable public policies into concrete implementation in conformity with legislative intentions and instructions.

According to Colley (2005) a secure, merit selected and politically neutral public service would be more efficient and able to provide frank and fearless advice to a government of any political persuasion. In an analysis of the extent to which Queensland (Australia) political parties politicized or depoliticized employment relations or used the workforce for their uniformity, Colley found that Labour Governments established the most independent and transparent institutions with strongest decision-making powers, and tended toward standardization and inclusion under public service regulation. On the other hand, Conservative governments favoured decentralization and departmental autonomy, which reduced uniformity and provided more scope for political influence in decisions and blurred the separation of politics from administration.

As Colley (2005) noted, it is ironical because central personnel agencies are tasked with maintaining an apolitical public service but yet they have featured in all political parties' election platforms over the years. Good government is usually synonymous with an efficient and effective public service. The effectiveness with which policies are implemented and services are delivered is dependent to a large extent on how these policies are formulated, implemented and evaluated. Under the career service model, a politically neutral public service is recruited on merit, and given tenure to encourage frank and fearless advice and protect it from electoral whims, thus enabling it to serve a government of any political persuasion.

Kernaghan (2009) outlined six key principles that should govern politics and administration interface in order to safeguard neutrality of the public service:

(1) Politics and policy are separated from administration - thus, politicians make policy decisions and public servants execute these decisions;

(2) Public servants are appointed and promoted on the basis of merit rather than of party affiliation or contributions

(3) Public servants do not engage in partisan political activities;

(4) Public servants do not express publicly their personal views on government policies or administration;

(5) Public servants provide forthright and objective advice to their political masters in private and in confidence; in return, political executives protect the anonymity of public servants by publicly accepting responsibility for departmental decisions; and

(6) Public servants execute policy decisions loyally, irrespective of the philosophy and programs of the party in 
power and regardless of their personal opinions

The political school rejects the politics-administration distinction as its proponents consider public administration as an inseparable part of the political process (Long, 1954; Bosworth, 1958; Pfiffner, 1985; Miller, 1993). Factors such as vague and ambiguous legislations, lack of technical knowledge and difficulties in monitoring and controlling bureaucratic behavior, are used to justify the critical role of public administrators in the policy process. Public administrators are viewed as policy makers and policy advocates. This approach rejects the subordinate and instrumental role of public administration in relating to elected officials. However, this fusion has its own challenges that forced the British public service in the $19^{\text {th }}$ century to detest when politicians were handing out public sector jobs to friends and supporters leading to corruption, favouritism, politicization and inefficiency. That is why the Northcote-Trevelyan Report (1853) appealed for a meritocratic system that would enhance public administration performance.

The interaction school emphasizes a high degree of collaboration between elected and administrative officials while maintaining each one's traditional roles and unique perspectives. In a sense, the interaction school seeks a middle ground between the separation and political schools. The interaction school acknowledges the differences between politics and administration in a number of ways such as logical and psychological differences between politics and administration, or dissimilarities in the perspectives, values, and formal positions of elected and administrative officials (Waldo, 1980; Nalbandian, 1994, Svara, 2001). Yet, what makes the interaction school somewhat different from the separation school is its emphasis on ongoing cooperation between elected and administrative officials in the process of policy making.

The relations between politics and management (administration) as Demir and Nyhan (2008) noted, is complex. In reality, a continuum rather than a dichotomy can be noted. Evidence from city managers in the United States demonstrated that there is a continuum in elected official-public administrator relations, which complicates the traditional view of dichotomy. The role overlaps between elected officials and public administrators on policy and administration are diverse, illuminating a more variable version of their relations (Demir 2009). New Public Management (NPM) movement calls for new ways of running governments just like business and reshaping the relations among politicians, administrators, markets and citizens. The strengthening role of administrators in the political process as well as the increasing involvement of politicians in process of policy implementation put more emphases on their interaction and complementarities (Svara 2001). Existing literature on this issue frequently agrees that in theory there is a division between political and administrative roles but in practice it is impossible to define a marked border between political and administrative actors (Chevallier, 2002; Mulgan, 2007).

\section{Role of Actors in Public Policy Processes in Malawi: Ministers and Principal Secretaries}

This section examines the role of ministers and PSs in policy processes in Malawi in order to determine the extent to which Malawi's experience reflect any of the models of politics and administration relationships discussed above.

In Malawi, ministers are 'political heads of government ministries'. Their roles in the public service machinery include among others, the provision of political leadership and direction of the ministries to which they are appointed. In this regard, they are accountable to the public on the performance of their ministry and as such they articulate policies aimed at enhancing the performance of their ministries. They are answerable to the president for the efficient performance of their ministries/ departments, and collectively, for the government. Principal Secretaries, on the other hand, provide professional leadership in their ministries, and are involved in policy formulation, strategic planning and management, financial management and human resource management. They are the contact points in the public service such that their effectiveness in discharging their responsibilities is critical to the ministries' performance. They are also viewed as executive heads of their ministries and departments in which they are responsible for day-to-day operations for all public service matters. As one key informant put it, PSs are essentially 'boundary spanners between the technical and the political structures in the ministry'. What role PSs and ministers playing public policy processes?

\subsection{Public Policy Formulation}

Public Policy had been defined by Dye (1995) as "whatever government chooses to do or not to do". Public policy process is also a series of related activities in the task of initiating, making, legitimizing; implementing, monitoring and evaluating policies in the public sector (Obasi, 2004). From the definitions it is evident that public policy results from the decisions of government to do something. Governments are usually faced with a number of issues that affects citizens such as HIV/AIDS, poverty, crime, drought and security to mention but a few. Since governments are 
usually seen as problem solvers they usually come up with a deliberate plan or decision to address issues of public concern. This involves various stages including policy formuation, impelmentation, monitoring and evaluation (1995). Implementation simply involves organizing, directing, planning, the activities of the government by the various actors such as the agencies, and departments.

Ministers formulate policies through Cabinet Committees of which they are members. At ministerial level, their role in policy formulation is to ensure that policies relating to smooth operations of their ministries are articulated and formulated. In this regard they provide direction to the principal secretaries in order to ensure that proper policies are formulated. They also take lead in determining policy objectives out of which PSs devise strategies for implementation. Once policies have been developed, ministers sign for them before they are submitted to the Cabinet for approval. The role of principal secretaries in policy formulation is 'to provide full, honest and impartial advice' to the ministers to enable them articulate proper policy decisions. As one key informant noted, 'they provide technical advice in the policy formulation process, as well as advice on how the policies can best be implemented'. At the operational level, they allocate resources such as human, material and financial and supervise the process of policy formulation. For example in the formulation process they might decide to organize a workshop where various stakeholders such as political leaders, civil servants, non- Governmental organizations and traditional leaders would discuss the issues before developing a draft policy for further refinement.

\subsection{Policy Implementation}

According to Hayes (2001), public policy implementation consists of organized activities by governments directed towards the achievement of goals and objectives, articulated in authorized policy statements. The process of policy implementation is affected by various factors such as the nature of the problem, circumstances surrounding them, the administrative machinery in charge of the task and the resources. In Malawi once policies have been formulated, ministers 'provide political leadership' in their implementation. The role of ministers in policy implementation as one respondent noted, is first 'to lobby for mobilization of resources for the effective implementation' of the policies.

At the start of the implementation of the policy, ministers preside over the ceremonial opening or placing a foundation stone. As the implementation process progresses, ministers also monitor how the policies are being implemented and provide direction where necessary. In this regard they provide checks and balances to ensure proper implementation of the articulated policies. It is not uncommon to hear on the radio, television or newspaper that such and such a minister is touring establishments in his ministry, and inspecting progress being made on projects he officially launched.

Principal Secretaries are implementers of the policies formulated by the ministers, and are required to update the ministers on the policy implementation process, and propose options for overcoming any obstacles in the policy implementation process. They implement the policies through officers below them such as deputy secretaries, directors, undersecretaries, chief human resource officers and various technical, professional and clerical staff including artisans. Their role is to implement the policy 'to the best of their ability and enable the ministries achieve their goals' of effective public service delivery. According to one respondent, 'PSs are therefore responsible for all the managerial functions of planning, organizing, directing, and coordination budgeting and reporting for the implementation of the policies'.

\subsection{Policy Monitoring and Evaluation}

Policy monitoring usually looks at whether the policy is working towards achieving the objectives of an organisation. Policy monitoring is the routine collection of data on a particular policy in order for management to asses the progress it is making in the implementation process. Administrators produce reports on a daily, monthly and quarterly basis. Policy monitoring examines the schedule (trend) of impact of the policy regardless of whether positive or negative. According to Dunn (1994) policy outcome is an observed consequence of policy action. He also points out that all the observed consequences could be intended or unintended. The impact of the policy includes impact on the target situation or group, impact on situations or groups.It also includes impact on future as well as immediate conditions, direct costs in terms of resources devoted to the program and indirect costs including loss of opportunities to do other things (Dye,1995).

In Malawi, ministers are responsible for ensuring that the policies they formulated with the help of PSs result in the expected impact or results. They are therefore keen to know the political consequences of their policies during or after implementation. They are responsible for the organization of policy reviews and recommendation of improvements where applicable to cabinet and or parliament Thus, during the evaluation process, a minister's role is to assess whether the policy objectives and goals were met and provide guidance on how to address the gaps if any. 
On the other hand, as one respondent noted, 'PSs are responsible for ensuring that they put in place mechanisms for evaluating the policies, and coordinate the process of reviewing these policies.' This can be done through regular management meetings with heads of sections, quarterly reports, mid-term evaluation as well as end of project evaluation. In some instances PSs 'use workshops to hear stakeholders' views and perception on successes of the policies. They also use consultants to undertake an independent review and provide a report on achievements and challenges as well as recommendations.' Thus, PSs normally brief their minister on the outcomes of the evaluations and advise on solutions.

From the above, what is evident is that there is some degree of division of labour between the minister and principal secretaries in policy formulation, implementation and evaluation. There is no clear cut dichotomy to suggest that ministers only formulate and principal secretaries only implement. Each one of them has a role in all policy processes. It can be concluded therefore that the integration school discussed above has more relevance to the context of Malawi with regards to the relationship between politics and administration in policy processes.

\section{Human Resource Management Processes the Malawi Public Service}

The main roles and responsibilities of top-level civil servants (or 'principal secretaries' as is the case in Malawi) in charge of ministries include managing the human resources of the ministry and to ensure increased productivity and quality of service to the citizenry. It is important to examine the human resource management processes in the Malawi public service in order to determine the nature and impact of the interface between elected politicians and administrative heads of ministries on people management because an efficient and effective public service machinery needs proper systems of appointments, promotion, transfers and discipline handling.

\subsection{Recruitment Selection and Appointment}

Recruitment is the process of generating a pool of capable people to apply for employment to an organisation (Armstrong, 2010). It involves searching the candidates for employment and stimulating them to apply for jobs in the organization. Selection is the process by which managers and others use specific instruments to choose from a pool of applicants a person or persons more likely to succeed in the jobs (Armstrong, 2010). Effective recruitment and selection practices identify job applicants with the appropriate level of knowledge, skills, abilities and other requirements needed for successful performance in a job or organization. Hiring people with the right skills or the highest level of these skills lead to positive economic outcomes for the organization. Hiring people with wrong set of skills leads to disaster for both the person and the organization. Appointment is the filling of vacant positions after selection (Dzimbiri, 2015).

According to public service procedures in Malawi, the principal secretary plays a very important part in the recruitment and selection process in a ministry. The principal secretary is required to ensure that the ministry has the right numbers of staff with the right knowledge, skills and attitudes, necessary to adequately support the minister in the implementation of the policies. Recruitment of staff and procurement of resources and other services will be based on the activities lined up to achieve the policies. Secondly, where good policies are in place they will lead to recruitment of suitable and qualified human resources that will perform in line with the policies, thereby making it easy for the principal secretary to manage the implementation process. However, the provision of financial resources, which is the responsibility of the minister, in the policy cycle may affect positively or negatively the motivation of human resources in the ministry.

The principal secretary's role in recruitment is to declare and recommend vacancies to the civil service commission for advertisement and selection before the PS makes appointment on the direction of the appropriate commission. Initially there was one public service commission established in 1961 and modeled on the British system. However, with expanding Malawi public service, several service commissions were created - teaching services commission, civil service commission, health service commission, judicial service commission, police service commission, prison service commission. So it is the appropriate commission that will receive information from the PS of a ministry on vacancies to fill and number of people, qualifications, skills and experience required. The appropriate commission advertises in the newspapers and government circulars; it also receives applications which the commission sends to the relevant PS of a ministry for shortlisting. Interviews are held by the commission with a PS or representative of the ministry on the panel of interviewers. The commission selects the right candidates and directs the principal secretary in the ministry to make appointment.

In practice, the procedure is followed for the majority of cases especially at junior levels. While various commissions such as civil service commission, teachers service commission, health service commission are responsible for the 
recruitment, promotion, discipline and transfer of certain cadres of officers in the public service, the top levels from under-secretaries to chief secretary to the government and chief executives of various parastatal bodies, commissions and government agencies are appointed by the president. However, as one PS noted, 'it is an open secret that some ministers influence recruitment through directing the top civil servants to employ relatives and friend's children'. What has been typical over the years is that successive governments have been characterized by appointment, promotion, transfer and dismissal of senior public servants of their choice without following proper procedures. There has been an outcry that appointment of principal secretaries, directors, chief executives of parastatals, city and municipal councils and other senior public servants, have 'always been politically influenced.'

For example political appointments of principal secretaries by successive presidents created a situation whereby the civil service swelled the number of PSs to 96 by 2015 against fewer ministries. This had created a situation where in one ministry one, like education, one would find three PSs, causing problems of overlaps and power struggles on who was in control of the ministry. As one senior public official noted, 'that is why the Chief Secretary to the Government has issued a circular to reduce the number of PSs in Government by demoting many to the status of Chief Directors.' Following the implementation of this circular, the number of principal secretaries has been scaled down to 21. The issue of political interference in appointment has been highlighted by the Public Service Reform Commission headed by the Vice President as one of the key perceptions held by various people in Malawi.

\subsection{Promotion}

Promotion as described by Snell and Bohlander (2007) refers to a change of assignment to a job at a higher level in the organisation and includes the expansion of benefits and managerial authority over other employees in return for higher pay, benefits and privileges. Psychologically, promotions help satisfy employees' needs for security, belonging and personal growth. Promotions should receive the same careful attention as any other employment decisions to minimize concerns by those who feel are more deserving than those promoted.

In the Malawi Public Service, the procedure for promotion is not different from recruitment, selection and appointment explained above. The relevant service commission advertises in the newspapers and government circulars, on the recommendation of the principal secretary of a ministry that has vacancies. The commission receives applications which it then forwards to the relevant ministry for shortlisting. Interviews are held by the commission with a representative of the ministry on the panel of interviewers. The commission selects the right candidates and directs the ministry (through the principal secretary) to promote the successful candidates. For other higher levels above S5, approvals for promotion is effected by the president on recommendation by the appropriate commission.

However, beyond this practical procedure, there are also political interference. Promotions can be made by the president with total disregard for overall public service staff establishment and budgetary considerations. As one key informer lamented, 'It is no wonder instead of having 40 PSs, we ended up having 96.' Respondents in the study cited the case of the Joyce Banda administration that directed the ministry of Education to promote all teachers who had stayed for long without being promoted. The consequence of these was the promotion of up to 20,000 teachers to PT4 when there was neither establishment nor budget provision for these new positions in the ministry of education. For over two years, the teachers had not been paid their new salary arrears due to budgetary constraints which could have been avoided if the process was under the control of the principal secretary in the ministry of education. One respondent cited the case of 'unqualified officers promoted to district commissioner positions in Neno, Chitipa and Machinga, forcing minister of local government to demote them back to where they belonged. The demotions were vehemently resisted through court injunctions, causing inconveniences and stalemate to service provision in the districts affected.

\subsection{Demotion}

Demotion is the process of reducing an employee's grade because of an act of underperformance or when an employee has misbehaved during his course of work and and as Araga (2008) noted, his behaviour does not befit him to hold that position. It is also part of disciplining the employee for an offence he has done while performing his duties or has failed to perform according to desired standard. An employer shall be entitled to take disciplinary action, other than dismissal, when it is reasonable to do so considering all circumstances and that disciplinary actions include demotion (Employment Act 2000) .

In the Malawi Public Service, demotion can occur due to a misconduct that has been investigated and duly handled according to the Malawi Public Service Regulations and Employment Act 2000. Demotion as a punishment is meted by the appropriate service commission. In practice this procedure is followed for the majority of the employees 
whose appointment or promotion is not handled by the the president or minister. However, demotions have come at times for senior positions on directives from above. The controversal case of district commissioners of Chitipa, Machinga and Chiradzulo who were demoted through a directive from the minister of Local Government was frequently cited by respodents to illustrate improper procedures in demotion.

Another controversal case demonstrating the negative role of ministers in the smooth fnctioning of the public service was that of a directve by the minister of local government that purpoted to abolish the position of chiefs in cities. This was severely protested by the concerned chiefs who gunnered support from fellow chiefs to challenge such a directive. Another example of a strange demotion cited was the appointment by the president of a chief secretary to the government to become a high commissioner after change of government. The implication of this is that the officer who was the supervisor of all principal secretaries in government started reporting to one of the principal secretaries in the ministry of foreign affairs. Such a situation could not have occured if proper procedures of appointment or transfer were employed because the officer never committed a misconduct except for the change of the government.

\subsection{Transfer}

Transfer is the placement of an employee in another job for which the duties, responsibilities, status pay and benefits are equal to those of the previous job ( Scott and George, 2007). On the other hand, Miner and Crane(1995) described it as reassignments to similar positions in other parts of the organisation. A transfer requires the employee to change work group, work place, work shift or organisational unit. Transfers make it possible for an organisation to place its employees in jobs where there is a greater need for their service and where they can acquire new knowledge and skills. Transfers can also be done to expose people to a wider range of jobs or to fill open positions with trained employees.

In the Malawi Public Service transfer can be between posts or a move to another work station where there is a vacancy to be filled. Transfer between posts occurs when for instance a secondary school teacher applies and succeeds in an interview for the post of protocol officer in the ministry foreign affairs. He will need to be transfrred between posts and move to the new work station. The process also involves the relevant service commission that conducted interviews notifying the relevant ministry of successful candidates and the transfer between posts will be a joint responsibility between the ministries of education and foreign affairs.

However, political trasfers are not uncommon. There has been cases cited about political interference where an Army Commander is transfereed to become a general managers in a parastetal body. Others cases cited are of politicans who have been sent to a parastal body to undertake senior management positions without open competention as expected of public service commission regulations and procedures. Cited also are cases of officials from a city council and university being transferred to a ministry but at higher levels, creating distortions in total establishment and morale problems in the receiving ministry and generally complicating public service human resource management practices. Secretaries have been transferred from one ministry to the other on directives from ministers wanting to have such a secretary for reasons known to themselves. Ministers are comfortable with support staff well known to them.

With the democratization of politics which allows change of government every five years, a tendency to break continuity seems to be the order of the day. When a new government comes in, a new Chief Secretary and new senior officers of the public service are ushered in and others are transferred elsewhere or forced to retire. The result of this is lack of continuity in experience and a tendency to make 'hay while it shines'. This means extracting resources for own benefits before a new Government comes in. Consequently, the citizen is always given a raw deal government after government, as efforts are not concentrated on good service delivery but quick schemes for self-enrichment and maximizing self-aggrandizement.

As one respondent noted, "political leaders have short term perspective when public servants have long-term perspective. Consequently, rational advice is not taken by political bosses who are motivated to achieve short term goals in a very costly and inefficient manner, with huge social cost to the citizenry.' The PSs end up operating in an unprofessional manner to please their political bosses and save their careers.

It is not surprising that there is a strong view that political intererefence exists in appointments and termination of employment in senior public offices during regime change. The Public Service Review Commission noted this perception in its consultation and therefore made a recommendation, in principle, that the position of Attorney General, Governor of the Reserve Bank of Malawi, Chief Secretary to Government, Director General of Malawi Broadcasting Corporation, Inspector General of Police, Commander of the Malawi Defence Force, Secretary to the Treasury and Budget Director should follow presidential tenure of office. This raises more fears that nepotism or favouritism which characterised the 19th century British Civil Service may be entrenched. What impact shall this 
system have on the performance of these public servants when they know that their careers terminate in five years' time and that they will have no opportunity to renew the contract? As one observer noted, the consequence shall be 'lack of contunity in organisational memory, inefficent utilisation of resources and deliberate extravagance between governments'.

\subsection{Discipline}

Discipline can be defined as actions or behavior on the part of authorities in an organization aimed at restraining all employees from behaviours that threaten to disrupt the functioning of the organization(Nel et al., 2007). It is the means by which supervisory personnel correct behavioural deficiencies and ensure adherence to established company rules. The purpose of discipline is to correct behaviour and not just to punish or embarrass an employee. Disciplinary procedures and corrective-action policies establish guidelines for employee performance and behavior and add an essential component to the overall management system. Disciplinary action initiated by management is a way of counteracting poor work performance and unacceptable worker's behavoiur. However a proper procedure must be followed in all disciplinary cases.

The Malawi Public Service Regulations stipulate 26 acts of misconduct including insubrodination, absenteeism, theft, corruption, involvement in party politics and financial embarrassment. The role of PSs in disciplining seniors public servants is to oversee the enforcement of discipline in their ministries to ensure that staff are adhering to public service code of ethics and conduct, Malawi Public Service Regulations, the Public Service Act, Employment Act, administrative circular letters and relevant statutes. Proper procedures for handling disciplinary matters which involve the officer/employee who has committed a misconduct, the controlling officer (PS) and the relevant service commission is also stipulated. The employee is interdicted while the alleged misconduct is being investigated and a hearing in which the officer is invited is held in a fair and transparent manner. The decision of the relevant commission be it demotion, transfer, withhold of increment or dismissal is communicated to the officer who has the right to appeal.

In practice there are issues of discipline that the public service commission reform has noted as prevalent in the Malawi public service. For instance, the commission noted that, 'there is a senior government management paralysis with regards to their supervisory roles; that junior staff continue to violate set rules and procedures, such as those relating to performance, time management, among others; that PSs and other Senior Government officials continue to ignore such acts and/or omissions which have put government business in a state of paralysis; there is also the camaraderie, "buddy-buddy" relationships that exist between the senior Government officials and their juniors' which the commission observed, "is responsible for a state of "mental siege" on the part of the senior government officials, and paralyses them into inaction. It was evident from the commission's sentiments that 'there is fear by Senior Government officials of their juniors as well as lack of respect by junior staff of their superiors. There is also 'absenteeism not sanctioned and is contrary to the provisions of the Malawi Public Service Regulations. The Commission noted that 'such unregulated absenteeism is leading to serious disruption of services and has a negative impact on delivery of services in most ministries, departments and agencies (MDAs)'.

That is why the reform commission recommended that Senior Government officials should exercise their mandates and discipline insubordinate staff without fear or favour, in line with Malawi Public Service Regulations.' Any absence from the office should be authorised, in line with the provisions and requirements of Malawi Public Service Regulations; and that 'all Controlling Officers be reminded that they have an obligation to enforce these regulations and ensure that Government services are always provided without disruption'. That senior officers be empowered to enforce the rules and regulations of the public service in their MDAs (GoM, 2014).

\subsection{Ministers and PS Relationships}

Attempts were made to explain the relationship between ministers and principal secretaries in Malawi. According to the key informants, 'the relationship between the minister and principal secretary in Malawi varies from one personality to another'. 'On average it is satisfactory, although in certain cases the professionalism of PSs may sometimes be compromised due to political pressures exerted by ministers especially in resource allocation'. After all, as another respondent noted 'PSs are political appointees and this sometimes makes it impossible for them to be apolitical'.

Thus, in other ministries, the relationship is harmonious whilst in other, it is 'uneasy and full of suspicion'. This leads to a number of challenges that PSs face. First, it was observed that the challenges PS face in managing human resources and service delivery include situations where both of them do not have common understanding and a shared vision of their ministry. Obviously they end up doing different things to the detriment of their ministries. 
They may not articulate good policies and recruit the right caliber of staff which in the long term may result in failure to manage the human resources as well as fare badly on service delivery.

Others noted that the minister and principal secretary may have different perspectives on the same ministry. The minister would always want to deliver results within the shortest possible time, in order to win the next election or return to power. As such he/she may want to take shortcuts in the implementation of the policies. On the other hand, the principal secretary would always want to follow correct administrative procedures. This often becomes the source of mistrust and conflict between the two. The other challenge is when ministers make 'ineffectual decisions' for PSs to implement. This brings frustration and low morale as professionalism is thrown away 'to the dogs'.

Examples of how PSs were instructed by ministers to implement certain policy decisions of the minister which were outside the relevant public service regulations were cited. These include a PS who was asked to open an account using a single signatory for the use by the minister and later the PS was interdicted and charged with misconduct, and eventually dismissed. Another case involved a minister who instructed a principal secretary to procure items outside the procurement procedures. This led to the interdiction on allegation of abuse of public office of the said principal secretary and subsequent disciplinary hearing and dismissal. Under such instances, 'PS are always victims yet the ministers come out clean'. At most some of these incidents are revealed when the minister's term is over or when new ministers have come in. As one PS noted, 'one dilemma is that when the PS stands his ground and says 'No' to an instruction from the minister, it is interpreted as insubordination'. A case was cited of a PS who refused to withdraw money from Government account having been directed from political boss and was subsequently removed from his position for some time before being posted to another institution outside the civil service.

Thus, a cordial relationship between ministers and principal secretaries in Malawi is paramount in the sense that for the two to perform effectively, they rely much on each other. This is so because they have distinct but complimentary roles. As stated earlier ministers provide political leadership and direction of ministries while principal secretaries professionally manage and administer day to day activities of the ministry. In order for them to perform effectively, they need to have good relationship by among other things having a common understanding as well as a shared vision of their ministries, open communication and participative management styles. This will ensure that all public servants are encouraged to perform to the best of their abilities; that good performance is recognized and properly rewarded and the reputation of each other and that of the ministry is not tarnished (Colley, 2005).

As one respondent pointed out, 'this requires reasonableness and understanding on both sides'. It was noted also that 'properly organised management meeting where staff can appreciate ones shortfalls and develop mutual trust,' should be the proper modus operanda in ministries to create a conducive political-administrative interface.

Apart from political interference in appointment and promotion in the public service, lack of ethics and accountability are another set of challenges. Lack of ethics and accountability in the public service has increased so much over the years. There are numerous cases reported over corrupt tendencies in the ministries and government departments, local government and parastatal bodies. In-spite of the various public sector reforms in the area of procurement, financial management and prevalence of a functioning service commissions, there are still public concerns about the prevalence of corrupt tendencies, moral decadence, nepotism in both recruitment and procurement. A terrible culture of allowances has created. This is a tendency among public servants to either create more workshops, seminars, training courses or jump from one holiday resort to another or one country to another (in the name of workshops) to enhance their own pockets through allowances. These have become more irresistible that officers give each other turns to attend workshops (Dzimbiri, 2014)

There is also evidence that the public service machinery has not been effective in recent years. There has been consistent lack of drugs in hospitals, severe vacancies in ministries and government departments when an army of the unemployed graduates swarm the streets (Dzimbiri, 2014) legal suits through unfair labour practices occasioned by premature termination of contracts of senior public servants upon entry of a new government, among others. The last quarter of the year 2013 witnessed a massive abuse of public funds popularly termed the cashgate scandal in which over MK 20 billion was syphoned from the public coffers. It is even feared that from 2005, Malawi must have lost close to MK 577 billion whereby both public servants and politicians were involved. This scandal affected Malawi's donor confidence that former president Joyce Banda had tried to rebuild when donors withheld it during the Bingu wa Mutharika's regime. The lost confidence resulted in the suspension of aid and loans to Malawi since 2013 (Jamali and Dzimbiri, 2015). 


\section{Conclusion}

The public service is the main tool governments use to implement various national development policies and deliver services in education, health, community development, transport, maintenance of law and order among others. Governments rely on this machinery to design, formulate and implement its policies, strategies and programmes, and to discharge all routine government functions. However, the relationship between politics and administration has been a controversial subject since the dawn of public administration as a field study. This paper has analyzed the role and impact of politics on human resource management in Malawi.

Central issues examined include the role of ministers and principal secretaries in recruitment, promotion, demotion transfer and discipline of public servants and determine the impact of that role on human resource management and service delivery in government departments. It was noted that, since the ministers play an advisory role in ensuring that that appropriate human resource is recruited, promoted or transferred, thereby improving service delivery. The role PSs play in recruitment, promotion transfer and discipline of senior public servants affect the delivery of service in that where staff with appropriate skills is recruited or promoted there will be effectiveness and efficiency in service delivery.

On the other hand, if principal secretaries have not given proper guidance in the process or if they do not enforce discipline, then the service delivery may be adversely affected. Again, where ministers interfere through directives on whom to appoint, promote or transfer, then morale and therefore, service delivery will be poor. There are reported cases of laxity and under-performance among public servants who willfully disregard procedures and regulations including late coming and early knocking off. Arrogance by junior staff, corruption, deliberate efforts to sell labour to citizens through solicitation of bribes before providing a service and generally slow service provision has been reported in the immigration, road traffic and other government departments.

It can be concluded that while at the formal level, ministers have not prominent role in recruitment, promotion, demotion or transfer of public servants in the ministry, the reality on the ground is quite different. Political interference in appointments, promotion, transfer and demotion of public servants is rampant in the public service. The consequence of this is ineffective service delivery due to frustrations, appointment of inappropriate human resources, legal suits due to premature termination of contracts, promotion without linking to budgetary provisions, bloated public service which becomes inefficient in the proper delivery of public service. It is evident from the discussion that the separation of politics and administration in Malawi does not exists. There is greater integration of the roles of ministers and PSs in policy processes. The system-wide recommendations for public sector reform titled, Making Malawi Work are implemented effectively, there is great likelihood that the public service human resource management function will raise its capacity to provide public services with great effectiveness and minimal political interference.

\section{Acknowledgement}

I wish to express my gratitude to the Research and Project Coordinators Professor Blessing Chinsinga and Mr Ernest Thindwa respectively and Professor Dan Banik of the Centre for Development and Environment, University of Oslo, for guidance, patience and good collaboration throughout the project. The funding agency, NORAD deserves very special thanks and deep appreciation for making available funding for the research project.

\section{References}

Anderson, J. E. (1984). Public Policy-Making. Holt, Rinehartand, Winston, Inc. Orlando, Florida.

Armstrong, A. (2010). A Handbook of Human Resources Management Practice. Kogan Page.

Bosworth, K. A. (1958). The manager is a politician. Public Administration Review, 18(3), 216-222. http://dx.doi.org/10.2307/973434

CAPAM (2007). Leading for Results: The Critical Role of the Permanent Secretary. Regional Seminar, January 21-23 Barbados.

Colley, L. (2005). Myth, Monolith or normative Model - Evolution of the career service model of employment in the Queensland Public Service 1859-2000, unpublished PhD Thesis, Griffith University, Business School.

Commonwealth Secretariat (2007). Report of the Workshop for Cabinet Ministers and Principal Secretaries in Lesotho. 
Demir T. (1993). Politics and administration: A review of research and some suggestions. University of Illinois at Springfield: Department of Public Administration.

Demir, T., \& Nyhan, R. C. (2008). The politics-administration dichotomy: An empirical search for correspondence between theory and practice. Public Administration Review, 68(1), 81-96. http://dx.doi.org/10.1111/j.1540-6210.2007.00839.x

DHRMD (2003). Comprehensive National Human Resource Survey. Lilongwe.

Dror, Y. (1967). Policy Analysis: a new professional role in government service. Public Administration Review, 27(3), 197-203. http://dx.doi.org/10.2307/973282

Dunn, D. D., \& Legge, J. S. (2002). Politics and administration in U.S. local governments. Journal of Public Administration Research and Theory, 12(3), 401-422.

Dunn, N. (1994). Public Policy Analysis: An Introduction. Prentice Hall, Inc., Englewood Cliffs: New Jersey. http://dx.doi.org/10.1093/oxfordjournals.jpart.a003540

Dye, T R. (1995). Understanding Public Policy. Prentice Hall, Inc., Englewood Cliffs: New Jersey.

Dye, T. R. (2005). Understanding Public Policy. Pearson Prentice Hall, New Jersey.

Dzimbiri, L. (2008). Experiences in New Public Management- the Case of Performance Management System in Botswana. Journal of Africa Development, 3(32), 42-58.

Dzimbiri, L. (2014). A History of Civil Service in Malawi. Unpublished Draft paper for the Public Sector Reform Management Unit. Lilongwe.

Dzimbiri, L. (2015). Organization and Management Theories: An African Focus- Integrating structure, people, environment and processes for human happiness. Zomba: Academic Publishers.

Government of Malawi (2014). Public Service Reform Commission: A Look at the Future Making Malawi Work Transforming Malawi's Public Service. Lilongwe

Hayes, W. (2001). The Public policy Web. Retrieved 12 July 2001 from http://www.geocities.com/profwork/implement/define.html

Jamali, T., \& Dzimbiri, L (2015). Malawi. In Elischer, S., Hofmeler, R., Mehler, A., \& Melber, H. (eds.), Africa Yearbook: Politics, Economy and Society South of the Sahara. Boston/Leden, Brill.

Johnstone, K. (2001). The Role of senior public servants in South Africa: lessons for the future. PhD Thesis, University of Capetown.

Kachimera, P. (2014). The History of the Public Service in Malawi. Unpublished Paper. Office of th President and Cabinet, Lilongwe.

Kathyola, J. (2010). The Political-Administrative Interface: the key to public sector governance and effectiveness in Commonwealth Africa. London. Commonwealth

Kithinji K. (1998). (ed.) Civil Service Reform in Southern and Eastern Africa Lessons of Experience. Report on Proceedings of a Consultative Workshop held at Arusha, Tanzania.

Long, N. (1954). Public policy and administration: The goals of rationality and responsibility. Public Administration Review, 14(1), 22-31. http://dx.doi.org/10.2307/972965

Miller, H. T. (1993). Everyday politics in public administration. American Review of Public Administration, 23(2), 99-116. http://dx.doi.org/10.1177/027507409302300202

Nalbandian, J. (1994). Reflections of a 'Pracademic' on the logic of politics and administration. Public Administration Review, 54(6), 531-536. http://dx.doi.org/10.2307/976672

Northcote, S., \& Trevelyan, G. (1853). Report on the Organisation of the Permanent Civil Service, 23 November 1853. Submitted to both Houses of Parliament by Command of Her Majesty in February 1854.

Pfiffner, J. P. (1985). Political public administration. Public Administration Review, 45(2), 352-356. http://dx.doi.org/10.2307/976157

Spanou, C. (2014). Administrative elites and the crisis: what lies ahead for the senior civil service in Greece. International Review of Administrative Sciences, 80(4), 709-725. http://dx.doi.org/10.1177/0020852314533453

Svara, J. H. (2001). The myth of the dichotomy: complementarity of politics and administration in the past and future 
of public administration. Public Administration Review, 61(2), $176-183$. http://dx.doi.org/10.1111/0033-3352.00020

Waldo, D. (1980). The enterprise of public administration: A summary view. Novato, CA: Chandler \& Sharp Publishers.

Walters, S. (2007). Working with Ministers: the Political and Administrative Interface. Leading for Results: The Critical Role of the Permanent Secretary. Regional Seminar, January 21-23, Barbados.

Wilson, W. (1887). The study of administration. Political Science Quarterly, 2, $197-222$. http://dx.doi.org/10.2307/2139277 